\title{
Abstinence activist to head US family planning
}

"Premarital sex is really modern germ warfare," read the PowerPoint slide presented at a 2003 abstinence conference by Eric Keroack.

Considering the source, this wasn't surprising. abortion opponent, had long been making the rounds on the right-to-life circuit, where he promotes the theory-based partly on research in prairie voles - that premarital sex depletes the hormone oxytocin, impairing young people's ability to form the social bonds needed for a stable marriage.

What is surprising is Keroack's appointment in November to become the Bush administration's top family-planning official.

As deputy assistant secretary of population affairs at the US Department of Health and Human Services (DHHS), Keroack will oversee a $\$ 283$ million budget that funds the government's only program dedicated to family planning. Called Title X, it has, since 1970, been providing counseling, contraceptives, abortion referrals and screening services-from Pap smears to HIV tests-to poor women. It serves about 5 million women each year.

"Dr. Keroack is a highly qualified and wellrespected physician," John Agwunobi, assistant Keroack, a Boston-area gynecologist and ardent

secretary for the DHHS, declared in a written statement. " $[\mathrm{He}]$ has developed extensive firsthand knowledge of the needs of young pregnant women and teen parents and has almost 20 years' experience in meeting those needs," Agwunobi said.

The DHHS has refused to make Keroack available for interviews. "We usually let folks get their feet on the ground and get settled in for a time in their position before putting them before the media," explained a spokesman.

Never mind that Elias Zerhouni was quoted in the media on the explosive issue of stem cells before he was sworn in as director of the National Institutes of Health, which falls under DHHS purview. Or that Surgeon General nominee Richard Carmona discussed AIDS and terrorism publicly with the Senate committee poised to pass muster on his nomination.

Keroack, 46, a Tufts Medical School graduate, was until recently medical director of A Woman's Concern, a network of six pregnancy counseling centers in eastern Massachusetts. The centers oppose contraception and advise abstinence until marriage. They do provide ultrasound scanning, which Keroack has used to dissuade pregnant women from having abortions.

\section{Australia embraces cloning research}

Australian scientists will be able to apply for a license to undertake therapeutic cloning research from mid-2007.

On 6 December, Australia's House of Representatives voted 82 to 62 in favor of a bill legalizing the creation of human embryos by somatic cell nuclear transfer and the harvesting of embryonic stem cells for research purposes.

The new law is a welcome move for Australian scientists, some of whom were rumored to be looking offshore for more supportive government regulations. In their campaign for the reforms, scientists avoided the term 'therapeutic cloning' to prevent any confusion with reproductive cloning.

"We used the term 'somatic cell nuclear transfer' so that we could then describe specifically what the technique was," says Stephen Livesey, chief executive officer of the Australian Stem Cell Centre. "I found that if you started off with 'therapeutic cloning, you couldn't get to the explanation."

The bill passed the Senate in November by the finest margin-34 to 32 .

Parliamentarians in both chambers were allowed a conscience vote, a rare freedom in a system where party-line voting is the norm. Studies will be administered by the National Health and Medical Research Council, the main source of funding for medical research in Australia. Licensing guidelines and procedures are expected to be finalized by July 2007, when at least five research institutions are expected to submit applications.

The law allows for the creation of human embryos other than by fertilization of a human egg by a human sperm, stipulating that these embryos must not be implanted into a woman and must be destroyed after 14 days.

A previous version also allowed for the creation of chimeras - created by inserting human DNA into enucleated animal eggs — but a Senate amendment outlawed such research.

The bill mandates licenses for therapeutic cloning, with a penalty of imprisonment for up to ten years for creating an embryo without a license and up to five years for working with such an embryo without a license.

Simon Grose, Canberra

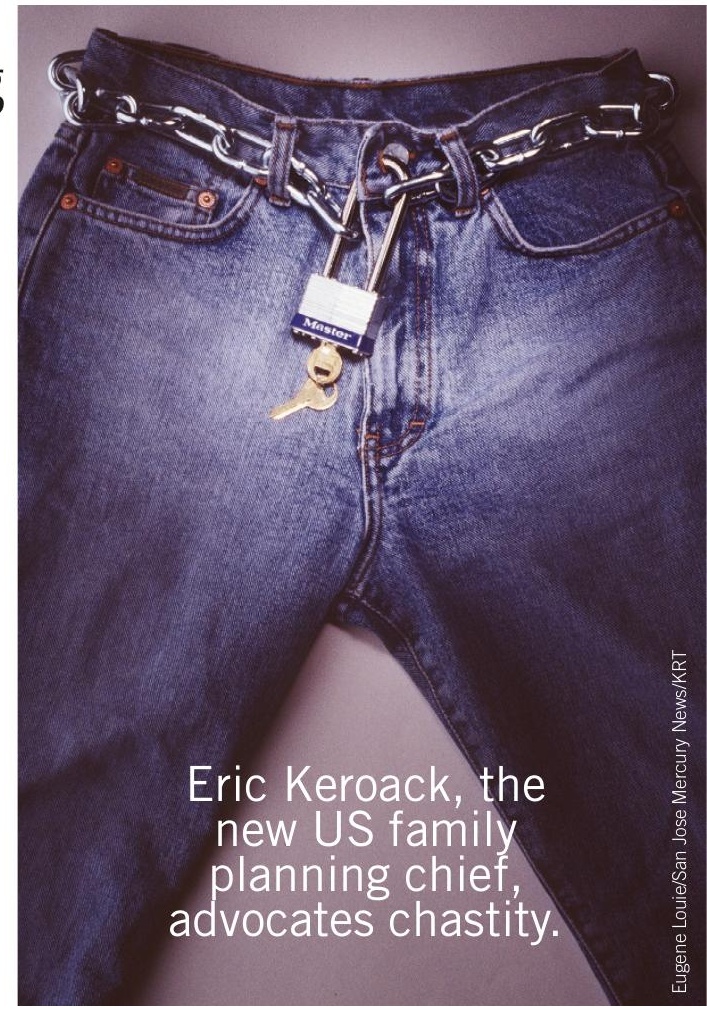

His appointment has outraged reproductive rights groups.

"This country needs someone in charge of the nation's family planning programs who is an advocate for family planning," says Elizabeth Toledo, vice president of communications for the Planned Parenthood Federation of America, which runs 860 health centers nationwide. "Dr. Keroack's appointment threatens the health of the nation's poorest women and we think it should be withdrawn immediately."

After the elections in November, when Democrats took control of the Congress, "We would have hoped that the Bush administration's practice of choosing ideology over competence would have been over," adds Sean Tipton, a spokesman for the American Society for Reproductive Medicine, which represents 8,500 medical professionals.

These groups and 24 others signed a 20 November letter to DHHS Secretary Michael Leavitt, demanding Keroack's ouster.

The normally staid American College of Obstetricians and Gynecologists also weighed in with its own letter, saying, "We urge this individual to advocate a wide range of family planning policies."

Predictably, Keroack's appointment has pleased the constituency at which it was aimed. "We think he's a good choice," says Wendy Wright, president of Concerned Women for America, an activist group whose mission is "to protect and promote Biblical values among all citizens."

Meredith Wadman, Washington DC 